\title{
Effect Of The IFRS Adoption On The Cost Of Capital: Evidence From Korea
}

Leem Wook-Bin, Hansung University, South Korea

Jee Hoon Yuk, Chung-Ang University, South Korea

\begin{abstract}
This study investigates whether the cost of capital of Korean listed firms was substantially reduced after the IFRS adoption in long-term aspect and which firms listed in KOSPI or KOSDAQ market had been more enjoyed the benefit. Prior studies related to this subject don't provided consistent results and have limitations of insufficiency of research periods and generalization problem. Therefore, this study analyzes the positive effect of the IFRS adoption in Korea using long-term based approach and differential measurements (CAPM and WACC) to facilitate generalization. Results of the study found that the cost of capital of Korean listed firms had been significantly reduced during 5 years after the IFRS adoption. In addition, the cost of capital of KOSPI listed firms was reduced more than KOSDAQ listed firms. The results provide meaningful implications to evaluate the effects of IFRS adoption on the cost of capital and to assess accomplishment of fundamental purpose of the IFRS adoption in Korea.
\end{abstract}

Keywords: IFRS; Cost of Capital; Capital Assets Pricing Model (CAPM); Weighted Average Cost of Capital (WACC)

\section{INTRODUCTION}

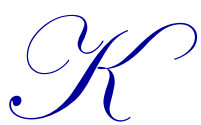

orea fully adopted the IFRS (International Financial Reporting Standards) in 2011 to solve 'Korea discount' problem derived from accounting transparency issue. Since the IFRS applies principle-based approach, it is possible to reflect the economic substance of firms more appropriately and to facilitate overseas funding and investment to Korean firms. In particular, in case of Korea, the IFRS was adopted voluntarily by the government, but individual firms were forced to adopt mandatorily. Therefore, Korea has unique characteristics in aspect that the effects of IFRS adoption can be found at both sides of voluntary and mandatory adoption at the same time.

One of the advantages of the IFRS adoption is reduction of cost of capital mainly due to decrease of information asymmetry and increase of stock market liquidity. Several prior studies such as Leuz and Verrechia (2000), Karamanou and Nishiotis (2005), Hail and Leuz (2007) suggests that firms' cost of capital was significantly reduced after the IFRS adoption. Furthermore, some studies which analyzed Korean firms such as Kim and Cho (2014) and Yoon (2014) report that the cost of capital of Korean firms was also reduced after the IFRS adoption. However, Kim and Cho (2014) and Yoon (2014) have limitations that they performed very short period analysis and their empirical results were difficult to be generalized. Consequently, they are insufficient to provide substantial effect of the IFRS adoption in Korea.

Meanwhile, stock markets in Korea consist of KOSPI and KOSDAQ market. Each stock market has distinctive characteristics. Specifically, firms listed in KOSDAQ market features that volatility of earnings tends to be higher than KOSPI listed firms and accordingly, required rate of return of investors also tends to be higher in KOSDAQ market than that of KOSPI market. Thus, if the cost of capital of Korean firms could be reduced after the IFRS adoption, it might be more remarkable reduction at KOSPI listed firms than KOSDAQ listed firms.

Therefore, this study analyzes whether the cost of capital of Korean firms was reduced for 5 years after the IFRS adoption in long-term aspect and whether there was a market difference (KOSPI and KOSDAQ) in cost of capital reduction. The results of this study show that the cost of capital of Korean firms was significantly reduced for 5 years after the IFRS adoption compared with 5 years of pre-IFRS adoption periods. Moreover, the cost of capital of KOSPI 
listed firms was reduced more than that of KOSDAQ listed firms. These results have implication that the IFRS adoption in Korea had positive effects on overall capital market even in the long term.

This study contributes that it tried to investigate economic effect of the IFRS adoption in Korea for relatively longterm period after the initial adoption whereas prior studies analyzed it in short-term. In addition, this study considers both cost of equity and cost of debt by using Capital Asset Pricing Model(CAPM) and Weighted Average Cost of Capital (WACC) in order to measure overall cost of capital. Thus, results of this study provide comprehensive insights to evaluate the effects of IFRS adoption on overall cost of capital.

\section{LITERATURE REVIEW AND HYPOTHESES}

The IFRS has been recognized as the highest quality accounting standards along with US GAAP, and accordingly the adoption of the IFRS has become a global trend. In compliance with this trend, a number of studies were performed on the capital market effects of the IFRS adoption. These studies were based on a conception that the liquidity of stock market would increase by the IFRS adoption and the cost of capital could be reduced resulting in the increase of the firm value.

For instance, Leuz and Verrechia (2000) and Karamanou and Nishiotis (2005) analyzed listed firms in Germany and reported that German listed firms experienced decrease of the cost of capital after the IFRS adoption. Specifically, Karamanou and Nishiotis (2005) suggested it was attributed to higher disclosure level of the IFRS than that of German accounting standards.

Hail and Leuz (2007) found that the cost of capital of firms which adopted the IFRS was lower than firms which didn't adopt the IFRS and market liquidity was improved after the IFRS adoption. Daske, Hail, Leuz \& Verdi (2008), which analyzed firms in $26 \mathrm{EU}$ member countries, also reported that market liquidity and firm value were increased whereas the cost of capital was decreased after the IFRS adoption. Moreover, Daske et al. (2008) argued that the IFRS adoption effects on capital market were higher for firms which adopted the IFRS voluntarily than for mandatorily adopted firms. And Daske et al. (2008) also suggested net effects of the IFRS adoption on the capital market were greater in countries where had solid legal and constitutional systems.

Li (2010), which studied effect of the IFRS adoption on the cost of equity of firms in EU member countries, also suggested that the cost of capital of firms which adopted the IFRS mandatorily was more reduced than firms which adopted the IFRS voluntarily. $\mathrm{Li}$ (2010) explained that the result was stemmed from improvements on disclosure level and comparability of accounting information after the IFRS adoption. And Daske, Hail, Leuz \& Verdi (2013) provided empirical evidence that firms which substantially adopted the IFRS improved the cost of capital and liquidity compared to firms which only nominally introduced the IFRS.

Kim and Cho (2014) which examined the economic effects of IFRS adoption in Korea reported that information asymmetry and the cost of capital was decreased after the IFRS adoption. Yoon (2014) also suggested that the cost of capital was significantly reduced after the IFRS adoption in Korea similar to Kim and Cho (2014). However, Kim and Cho (2014) and Yoon (2014) analyzed only for 2 years right after the IFRS adoption ${ }^{1}$. Hence, their results are insufficient to test substantial IFRS adoption effect in Korea.

Unlike these studies, some papers such as Ormrod and Taylor (2004), Beattie, Edwards \& Goodacre (2006) reported that the adoption of the IFRS might lead to increase of the cost of capital. They argued that adoption of the IFRS required to rewrite financial statements and it might lead to significant changes in accounting figures. If so, the IFRS adoption might increase debt-ratio, lower credit rating and finally result in increase of the cost of capital.

Nevertheless, the IFRS requires higher level of disclosure in financial reporting than local accounting standard (Ashbaugh \& Pincus 2001). Therefore, if a country or a firm adopts the IFRS as its accounting standard, disclosure level would be extended and information asymmetry would be reduced. As a result, the cost of capital is expected to

\footnotetext{
${ }^{1}$ Specifically, Kim and Cho (2014) analyzed only for two years treating 2009 as pre-IFRS period and 2012 as post-IFRS period. Yoon (2014) also has a limitation that it just treated 2011 and 2012 as post-IFRS period. 
be decreased compared to periods before the IFRS adoption (Botosan, 1997; Easley \& O' Hara, 2004; Lambert, Leuz \& Verrecchia, 2007).

In addition, the IFRS can improve comparability of accounting information contained in financial statements as it is applied almost identically to countries adopting it. The improvement on the comparability of accounting information may lower information acquisition costs of investors and as a result, information asymmetry can also be reduced (Armstrong, Barth, Jagolinzer \& Riedl, 2010). Therefore, we establish the first hypothesis as below;

Hypothesis 1: The cost of capital of Korean listed firms would be reduced after the IFRS adoption in comparison with the pre-IFRS adoption.

Financial Supervisory Service (FSS) of Korea, one of the governmental regulators, announced the IFRS adoption roadmap in March 2007. According to the announcement, all Korean listed firms which were listed in not only KOSPI but also KOSDAQ market were to adopt and apply the IFRS since $2011^{2}$. However, since the period from the roadmap announcement (2007) to the enforcement (2011) of the IFRS was relatively very short, several practical problems such as the change of computer system, understanding and learning new standard were expected to prepare the IFRS adoption fully.

In particular, considering the ability of accountants and affordability of investment on new systems, such problems were to be more burdened for KOSDAQ listed firms than KOSPI listed firms because firm size of KOSDAQ listed firms was generally smaller than that of KOSPI listed firms. Accordingly, if firms could enjoy their reduction of the cost of capital after the IFRS adoption, this positive effect would be turned up more strongly at KOSPI listed firms than KOSDAQ listed firms.

Moreover, KOSDAQ listed firms had specific characteristics that their inherent risks were relatively higher than those of KOSPI listed firms and the KOSDAQ market itself was established to provide promising investment opportunities to investors who were willing to take high risk and high return. In addition, the volatility of earnings of KOSDAQ listed firms tended to be higher than that of KOSPI listed firms. Based on those characteristics, investors' potential required rate of return in KOSDAQ market was higher than that in KOSPI market (Han 2005; Cha 2008). Accordingly, it is expected for KOSPI listed firms to experience greater decrease of the cost of capital than KOSDAQ listed firms. Hence, we establish the second hypothesis as below;

Hypothesis 2: The cost of capital reduction effect after the IFRS adoption would be greater for KOSPI listed firms than KOSDAQ listed firms.

\section{RESEARCH DESIGN}

\section{Research Model}

The research models for testing hypotheses 1 and 2 are as follows:

$$
\begin{aligned}
& \operatorname{COE}(W A C C)_{i t}=\alpha_{0}+\alpha_{1} I F R S_{i t}+\alpha_{2} S I Z E_{i t}+\alpha_{3} L E V_{i t}+\alpha_{4} M B_{i t}+\alpha_{5} R O A_{i t}+\alpha_{6} O C F_{i t}+ \\
& \alpha_{7} O W N E R_{i t}+\alpha_{8} F O R G I_{i t}+\alpha_{9} B I G 4_{i t}+I N D+Y D+e \\
& \operatorname{COE}(W A C C)_{i t}=\alpha_{0}+\alpha_{1} I F R S_{i t}+\alpha_{2} \text { KOSPI }_{i t}+\alpha_{3} I F R S * K O S P I_{i t}+\alpha_{4} S I Z E_{i t}+\alpha_{5} L E V_{i t} \\
& +\alpha_{6} M B_{i t}+\alpha_{7} R O A_{i t}+\alpha_{8} O C F_{i t}+\alpha_{9} O W N E R_{i t}+\alpha_{10} F O R G I_{i t}+\alpha_{11} B I G 4_{i t}+I N D+Y D+e
\end{aligned}
$$

\footnotetext{
${ }^{2}$ All listed firms in Korea have mandatorily applied the IFRS as their accounting standard since 2011, whereas unlisted firms have applied KoreanGAAP which has been established and revised by the Korean Accounting Standards Board (KASB). It is permitted for unlisted firms to apply the IFRS voluntarily, however any listed firms are not allowed to apply the Korean-GAAP.
} 


$\begin{array}{ll}\text { COE: } & \text { Cost of equity measured by CAPM; } \\ \text { WACC: } & \text { Weighted average cost of capital; } \\ \text { IFRS: } & 1 \text { if post-IFRS and } 0 \text { otherwise; } \\ \text { KOSPI: } & 1 \text { if KOSPI listed firm and } 0 \text { otherwise; } \\ \text { SIZE: } & \text { The natural logarithm of total assets; } \\ L E V: & \text { Total liabilities divided by beginning total assets; } \\ M B: & \text { Market value divided by book value; } \\ \text { ROA: } & \text { Net income divided by beginning total assets; } \\ O C F: & \text { Operating cash flows; } \\ \text { OWNER: } & \text { Ownership of the largest shareholder and related parties; } \\ \text { FORGI: } & \text { Ownership of foreign investors; } \\ \text { BIG4: } & 1 \text { if the auditor belongs one of Big } 4 \text { and } 0 \text { otherwise; } \\ \text { IND: } & \text { Industry dummy; } \\ Y D: & \text { Year dummy }\end{array}$

The cost of capital consists of two components; cost of equity and cost of debt capital. However, most prior studies on the cost of capital tended to focus on one of the two components. Francis, Khurana \& Pereira (2005) pointed out if focusing on cost of equity only, the effect of cost of debt capital might be neglected and vise versa. Hence, this study considers both cost of equity and cost of debt capital by using Capital Assets Pricing Model (CAPM) and Weighted Average Cost of Capital(WACC) to measure overall cost of capital.

In particular, Gode and Mohanram (2003) model and Easton (2004) model which have been used by most prior studies to measure cost of equity essentially need earnings forecasts of financial analysts. However, in case of Korea, only one third of the KOSPI listed firms provide earnings forecasts of financial analysts and the portion tends to be even lower at KOSDAQ listed firms. Accordingly, it is difficult to generalize the result of analysis on cost of equity of Korean listed firms when estimating by models using earnings forecasts ${ }^{3}$. Moreover, according to McInnis (2010) and Francis et al. (2005), earnings forecasts of financial analysts have a problem in that they may be biased optimistically.

Therefore, this study uses CAPM and WACC provided by Korean Database KIS-Value as measurement of the cost of capital. Since CAPM as well as WACC provided by KIS-VALUE are calculated for almost all KOSPI and KOSDAQ listed firms, using these measurements is able to minimize practical problems related to the representative of sample and generalization of results.

Main explanatory variable of Equation (1) which tests for hypothesis 1 is IFRS. Therefore, if estimated coefficient of $\alpha_{1}$ has significant negative value, hypothesis 1 which predicts the cost of capital of Korean listed firms was reduced after the IFRS adoption can be supported.

Main explanatory variable of Equation (2) which tests for hypothesis 2 is IFRS*KOSPI. Accordingly, if estimated coefficient of $\alpha_{3}$ has significant negative value, hypothesis 2 which predicts the cost of capital reduction effect after IFRS adoption would be greater for KOSPI listed firms can be supported. Control variables (SIZE, LEV, MB, ROA, OCF, OWNER, FORGI, BIG4) are included following related prior studies.

\section{Sample Selection}

This study analyzed all listed firms in KOSPI and KOSDAQ market from 2006 to 2015. Specifically, this study treated 2006 2010 as pre-IFRS period and 2011 2015 as post-IFRS period respectively. Sample firms were selected from the following conditions.

(1) Firms listed in KOSPI and KOSDAQ market from 2006 to 2015

(2) Non-financial firms

(3) Firms which close their books in December

\footnotetext{
${ }^{3}$ Yoon(2014) measured cost of equity by models using earnings forecasts of financial analysts. In this regard, empirical results of Yoon(2014) have another limitation to be generalized. 
(4) Firms with data available on KIS-VALUE

(5) Firms without impaired capital, not under administration, and not delisted

All data for the analysis was collected from KIS-VALUE and extreme values of all variables were winsorized at $1 \%$ level of both tale. The final firm-year observations were 14,108 $(n=14,108)$.

\section{EMPIRICAL RESULTS}

\section{Descriptive Statistics and Correlation Analysis}

Table 1 shows descriptive statistics of variables included in Equation (1) and (2). The average of cost of equity (COE) is 8.5766 and the average of weighted average cost of capital (WACC) is 6.0595 respectively. These figures mean Korean listed firms have been effectively lowering overall cost of capital by utilizing debt as well as equity in capital market rather than financing only by equity capital. The average of IFRS is 0.5543 , which means about $55 \%$ of total observations consist of the period after the IFRS adoption. In addition, the average of KOSPI is 0.4174 , that is, KOSPIlisted firms consists about $42 \%$ of total observations. Thus, the sample composition for the analysis is relatively stable. Table 2 presents Pearson correlation between variables. It shows that both $C O E$ and $W A C C$ have significant negative correlation with IFRS. Thus, it can be supposed that overall cost of capital was significantly decreased after the IFRS adoption. Moreover, $C O E$ and $W A C C$ also have negative correlation with KOSPI. Accordingly, it can be guessed the cost of capital of KOSPI listed firms was more reduced significantly than cost of capital of KOSDAQ listed firms after the IFRS adoption.

Table 1. Descriptive Statistics $(n=14,108)$

\begin{tabular}{l|c|c|c|c|c|r|r}
\hline & Mean & Std. & Min. & 1Q & Median & 3Q & Max. \\
\hline COE & 8.5766 & 2.7868 & 2.3500 & 6.5600 & 8.5300 & 10.5700 & 15.1100 \\
\hline WACC & 6.0595 & 1.9528 & 0.0000 & 5.0471 & 6.1646 & 7.2793 & 10.4449 \\
\hline IFRS & 0.5543 & 0.4971 & 0.0000 & 0.0000 & 1.0000 & 1.0000 & 1.0000 \\
\hline KOSPI & 0.4174 & 0.4932 & 0.0000 & 0.0000 & 0.0000 & 1.0000 & 1.0000 \\
\hline SIZE & 25.7458 & 1.3886 & 23.4052 & 24.7997 & 25.4590 & 26.4042 & 30.4235 \\
\hline$L E V$ & 0.4423 & 0.2437 & 0.0331 & 0.2517 & 0.4257 & 0.5979 & 1.2409 \\
\hline MB & 1.0242 & 1.1811 & 0.0891 & 0.3756 & 0.6456 & 1.1685 & 7.5968 \\
\hline ROA & 0.0241 & 0.1146 & -0.4770 & -0.0018 & 0.0332 & 0.0776 & 0.3222 \\
\hline OCF & 0.0515 & 0.1052 & -0.2775 & -0.0034 & 0.0476 & 0.1059 & 0.3821 \\
\hline OWNER & 0.2745 & 0.1416 & 0.0486 & 0.1683 & 0.2480 & 0.3532 & 0.7008 \\
\hline FORGI & 0.0647 & 0.1123 & 0.0000 & 0.0021 & 0.0135 & 0.0721 & 0.5618 \\
\hline BIG4 & 0.5551 & 0.4970 & 0.0000 & 0.0000 & 1.0000 & 1.0000 & 1.0000 \\
\hline & & & & & & &
\end{tabular}

Table 2. Pearson Correlation Matrix $(\mathrm{n}=14,108)$

\begin{tabular}{|c|c|c|c|c|c|c|c|c|c|c|c|c|}
\hline & $V 1$ & $V 2$ & V3 & $V 4$ & $V 5$ & V6 & $V 7$ & $V 8$ & V9 & V10 & V11 & V12 \\
\hline$C O E(V 1)$ & 1.00 & & & & & & & & & & & \\
\hline$W A C C(V 2)$ & 0.65 & 1.00 & & & & & & & & & & \\
\hline $\operatorname{IFRS}(V 3)$ & -0.38 & -0.25 & 1.00 & & & & & & & & & \\
\hline KOSPI (V4) & -0.16 & -0.14 & -0.04 & 1.00 & & & & & & & & \\
\hline SIZE (V5) & 0.01 & -0.08 & 0.09 & 0.56 & 1.00 & & & & & & & \\
\hline$L E V(V 6)$ & 0.10 & 0.01 & -0.08 & 0.08 & 0.20 & 1.00 & & & & & & \\
\hline$M B(V 7)$ & 0.12 & 0.07 & 0.05 & -0.18 & -0.13 & -0.08 & 1.00 & & & & & \\
\hline$R O A(V 8)$ & 0.03 & -0.10 & -0.05 & 0.04 & 0.16 & -0.14 & 0.15 & 1.00 & & & & \\
\hline$O C F(V 9)$ & 0.01 & -0.05 & -0.02 & -0.03 & 0.08 & -0.14 & 0.14 & 0.52 & 1.00 & & & \\
\hline OWNER (V10) & -0.12 & -0.12 & 0.03 & 0.06 & 0.07 & -0.02 & -0.04 & 0.13 & 0.09 & 1.00 & & \\
\hline FORGI (V11) & -0.01 & -0.01 & -0.03 & 0.26 & 0.46 & -0.08 & 0.13 & 0.17 & 0.16 & 0.04 & 1.00 & \\
\hline$B I G 4$ (V12) & 0.02 & -0.04 & -0.01 & 0.24 & 0.37 & 0.02 & 0.01 & 0.12 & 0.10 & 0.12 & 0.23 & 1.00 \\
\hline
\end{tabular}

Notes: The lower triangle presents Pearson correlation coefficients. Boldfaced figures are statistically significant at the $5 \%$ level 


\section{Results of Hypotheses}

Table 3 provides test results of hypothesis 1 . IFRS has significant negative association with both COE and WACC. In addition, all control variables included in the model are also significantly associated with dependent variables $(C O E$ and $W A C C$ ). Therefore, even controlling effects of other variables, hypothesis 1 which expects the cost of capital of listed firms in Korea would be reduced after the IFRS adoption compared with the pre-IFRS adoption is supported.

Table 4 provides test results of the hypothesis 2 . As in Table 3, Table 4 also shows significant negative association between IFRS and dependent variables (COE and WACC). And KOSPI has significant negative association with $W A C C$ as well as COE. It means KOSPI listed firms were generally borne lower level of capital costs than KOSDAQ listed firms. IFRS*KOSPI also shows significant negative associations with overall cost of capital (COE and WACC). Combing these results, it is supposed that the IFRS adoption in Korea had a positive effect on listed firms in respect of reducing the cost of capital even in long term perspective. Specifically, KOSPI listed firms enjoyed the benefit more than KOSDAQ listed firms. Hence, hypothesis 2 as well as hypothesis 1 are supported.

Table 3. Results of Hypothesis 1

\begin{tabular}{|c|c|c|}
\hline & $C O E$ & $W A C C$ \\
\hline & $\begin{array}{c}\text { Coefficient } \\
\text { (t-stat.) }\end{array}$ & $\begin{array}{c}\text { Coefficient } \\
\text { (t-stat.) }\end{array}$ \\
\hline \multirow{2}{*}{ Intercept } & $2.5836^{* * *}$ & $5.2263^{* * *}$ \\
\hline & $(5.42)$ & $(15.14)$ \\
\hline \multirow{2}{*}{ IFRS } & $-1.9106^{* * * *}$ & $-1.1323^{* * *}$ \\
\hline & $(-26.14)$ & $(-21.38)$ \\
\hline \multirow{2}{*}{$S I Z E$} & $0.2486^{* * *}$ & $0.0501^{* * *}$ \\
\hline & $(13.11)$ & $(3.65)$ \\
\hline \multirow{2}{*}{$L E V$} & $0.4283^{* * *}$ & $-0.4451^{* * *}$ \\
\hline & $(4.8)$ & $(-6.89)$ \\
\hline \multirow[b]{2}{*}{$M B$} & $0.3876^{* * *}$ & $0.1988^{* * *}$ \\
\hline & $(20.8)$ & $(14.72)$ \\
\hline \multirow{2}{*}{$R O A$} & 0.0601 & $-2.2470^{* * *}$ \\
\hline & $(0.28)$ & $(-14.59)$ \\
\hline \multirow{2}{*}{$O C F$} & $-0.6639^{* * *}$ & 0.0268 \\
\hline & $(-2.92)$ & $(0.16)$ \\
\hline \multirow{2}{*}{ OWNER } & $-1.6751^{* * *}$ & $-1.0372^{* * *}$ \\
\hline & $(-11.57)$ & $(-9.89)$ \\
\hline \multirow{2}{*}{$F O R G I$} & $-2.1469^{* * *}$ & $-0.3017^{*}$ \\
\hline & $(-10.09)$ & $(-1.96)$ \\
\hline \multirow{2}{*}{$B I G 4$} & 0.0189 & $-0.1184^{* * *}$ \\
\hline & $(0.43)$ & $(-3.68)$ \\
\hline$I N D$ & Included & Included \\
\hline$Y D$ & Included & Included \\
\hline Adj. $\mathrm{R}^{2}$ & 0.2724 & 0.2226 \\
\hline Obs. & 14,108 & 14,108 \\
\hline
\end{tabular}


Table 4. Results of Hypothesis 2

\begin{tabular}{|c|c|c|}
\hline & $C O E$ & $W A C C$ \\
\hline & $\begin{array}{c}\text { Coefficient } \\
\text { (t-stat.) }\end{array}$ & $\begin{array}{c}\text { Coefficient } \\
\text { (t-stat.) }\end{array}$ \\
\hline \multirow{2}{*}{ Intercept } & $-3.4604^{* * *}$ & $2.5396^{* * *}$ \\
\hline & $(-6.72)$ & $(6.70)$ \\
\hline \multirow{2}{*}{ IFRS } & $-1.8729^{* * *}$ & $-1.0101^{* * * *}$ \\
\hline & $(-23.91)$ & $(-17.53)$ \\
\hline \multirow{2}{*}{ KOSPI } & $-1.2314^{* * *}$ & $-0.3896^{* * *}$ \\
\hline & $(-18.41)$ & $(-7.92)$ \\
\hline \multirow{2}{*}{$I F R S * K O S P I$} & $-0.2528^{* * *}$ & $-0.3694^{* * *}$ \\
\hline & $(-3.17)$ & $(-6.3)$ \\
\hline \multirow{2}{*}{ SIZE } & $0.5057^{* * *}$ & $0.1617^{* * *}$ \\
\hline & $(24.33)$ & $(10.58)$ \\
\hline \multirow{2}{*}{$L E V$} & $0.2656^{* * *}$ & $-0.5160^{* * *}$ \\
\hline & $(3.05)$ & $(-8.05)$ \\
\hline \multirow{2}{*}{$M B$} & $0.3357^{* * *}$ & $0.1760^{* * *}$ \\
\hline & $(18.38)$ & $(13.09)$ \\
\hline \multirow{2}{*}{$R O A$} & -0.0919 & $-2.3353^{* * *}$ \\
\hline & $(-0.44)$ & $(-15.31)$ \\
\hline \multirow{2}{*}{$O C F$} & $-1.0015^{* * *}$ & -0.1059 \\
\hline & $(-4.51)$ & $(-0.65)$ \\
\hline \multirow{2}{*}{ OWNER } & $-1.5932^{* * *}$ & $-0.9861^{* * *}$ \\
\hline & $(-11.28)$ & $(-9.49)$ \\
\hline \multirow{2}{*}{ FORGI } & $-2.0805^{* * *}$ & $-0.2830^{*}$ \\
\hline & $(-10.03)$ & $(-1.85)$ \\
\hline \multirow{2}{*}{$B I G 4$} & $0.0741^{*}$ & $-0.0950^{* * *}$ \\
\hline & $(1.71)$ & $(-2.98)$ \\
\hline$I N D$ & Included & Included \\
\hline$Y D$ & Included & Included \\
\hline Adj. $R^{2}$ & 0.3086 & 0.2382 \\
\hline Obs. & 14,108 & 14,108 \\
\hline
\end{tabular}

Notes: $* * *, * * *$ represent significance at the 10,5 , and 1 percent levels, respectively.

\section{SUMMARY AND CONCLUSION}

Korea adopted the IFRS fully as its accounting standard in 2011 and it has been a critical research subject how the IFRS adoption effect is turned out. According to prior studies, one of the positive effects of the IFRS adoption is reduction of firms' cost of capital. However, those studies did not reported consistent results for that issue. Some studies which analyzed Korean IFRS adoption case suggest that the cost of capital of Korean listed firms was lowered after the IFRS adoption, but those studies have limitations with regard to research periods and generalization of results.

Thus, this study analyzed Korean evidence of the IFRS adoption effect with respect to reduction of the cost of capital in long term perspective. Especially, this study investigated which firms listed in KOSPI market or KOSDAQ market more enjoyed the benefit. The cost of capital was measured by CAPM and WACC in order to maximize possibility of generalization. In addition, this study utilized 5 year periods as pre-IFRS and post-IFRS, respectively.

Empirical results found that overall cost of capital of Korean listed firms were significantly reduced during 5 years after the IFRS adoption regardless of their listing market. Moreover, the effect of the cost of capital reduction was greater at KOSPI listed firms than KOSDAQ listed firms. It is considered that these results were attributed to the following Korean specific characteristics; First, Korean government decided the IFRS adoption voluntarily but all listed firms in Korea were forced to apply it mandatorily. Second, Korea was a substantial adaptor rather than nominal adaptor. Finally, Korea was one of countries where had solid legal and constitutional systems. 
This paper is differentiated from prior studies as it investigated the IFRS adoption effect using long-term based approach. Furthermore, this study included almost all Korean listed firms by utilizing differential measurements in order to facilitate generalization. This study has meaningful implications to assess whether fundamental purpose of the IFRS adoption in Korea was achieved.

\section{REFERENCES}

Armstrong, C. S., Barth, M. E., Jagolinzer, A. D. \& Riedl, E. J. (2010). Market reaction to the adoption of IFRS in Europe. The Accounting Review, 85(1), 31-61.

Ashbaugh, H., \& Pincus, M. (2001). Domestic Accounting standards, international accounting standards, and the predictability of earnings. Journal of Accounting Research, 39(3), 417-434.

Beattie, V., Edwards, K., \& Goodacre, A. (2006). International lease accounting reform and economic consequences: The views of UK users and preparers. International Journal of Accounting, 41(1), 75-103.

Botosan, C. A. (1997). Disclosure Level and the Cost of Equity Capital. The Accounting Review, 72(3), 323-350.

Cha, S. M. (2008). Information Effects and Transfers Associated with the Disclosure of Financially Distressed Firms in the KOSDAQ market: Focused on the comparison with the KSE market. Accounting Information Review, 26(4), 62-95.

Daske, H., Hail, L., Leuz, C., \& Verdi, R. (2008). Mandatory IFRS reporting around the world: Early evidence on the economic consequences. Journal of Accounting Research, 46(5), 1085-1142.

Daske, H., Hail, L., Leuz, C. \& Verdi, R. (2013). Adopting a label: Heterogeneity in the economic consequences around IAS/IFRS Adoptions, Journal of Accounting Research, 51(3), 495-547.

Easley, D. \& O' Hara, M. (2004). Information and the cost of capital. The Journal of Finance, 59(4), 1553-1583.

Easton, P. D. (2004). PE ratios, PEG ratios and estimating the implied expected rate of return on equity capital. Accounting Review, 79(1), 73-95.

Francis, J. R., Khurana, I. K., \& Pereira, R. (2005). Disclosure incentives and effects on cost of capital around the world. The Accounting Review, 80, 1125-1162.

Gode, D. \& Mohanram, P. (2003). Inferring the cost of capital using the Ohlson-Juettner Model. Review of Accounting Studies, 8, 399-431.

Hail, L. \& Leuz, C. (2007). Capital market effects of mandatory ifrs reporting in the eu: Empirical evidence. Working Paper. University of Pennsylvania, University of Chicago.

Han, K. S. (2005). The effect of corporate divestiture announcements on shareholder wealth in KOSDAQ market. Korean Business Education Review, 38, 401-427.

Karamanou, L. \& Nishiotis, G. (2005). The valuation effects of firm voluntary adoption of international accounting standards. Working Paper, University of Cyprus.

Kim, Y. S. \& Cho, S. M. (2014). The economic consequences of financial reporting under K-IFRS. Korean Accounting Journal, 23(2), 73-103.

Lambert, R. A., Leuz, C. \& Verrecchia, R. E. (2007). Accounting information, disclosure and the cost of capital. Journal of Accounting Research, 45, 385-420.

Leuz, C. \& Verrecchia. R. E. (2000). The economic consequences of increased disclosure. Journal of Accounting Research, 38(3), 91-124.

Li, S. (2010). Does mandatory adoption of international financial reporting standards in the European Union reduce the cost of equity capital? The Accounting Review, 85(2), 607-636.

McInnis, J. (2010). Earnings smoothness, average returns, and implied cost of equity capital. The Accounting Review, 85(1), 315341.

Ormrod, P. \& Taylor, P. (2004). The impact of the change to international accounting standards on debt covenants: A UK perspective. Accounting in Europe, 1, 71-94.

Yoon, S. R. (2014). Empirical evidence on the relationship between mandatory adoption of IFRS and the cost of equity capital. Journal of International Trade \& Commerce, 10(1), 883-909. 